\title{
Whose butt is it? tobacco industry research about smokers and cigarette butt waste
}

\author{
Elizabeth A Smith, ${ }^{1}$ Thomas E Novotny ${ }^{2}$
}

${ }^{1}$ Department of Social and Behavioral Sciences, University of California San Francisco, San Francisco, California, USA ${ }^{2}$ Graduate School of Public Health, San Diego State University, San Diego, California, USA

\section{Correspondence to}

Elizabeth A Smith, University of California San Francisco, Box 0612, San Francisco, California 94143, USA;

libby.smith@ucsf.edu

Received 16 September 2010 Revised 29 November 2010 Accepted 17 December 2010

\begin{abstract}
Background Cigarette filters are made of nonbiodegradable cellulose acetate. As much as 766571 metric tons of butts wind up as litter worldwide per year. Numerous proposals have been made to prevent or mitigate cigarette butt pollution, but none has been effective; cigarette butts are consistently found to be the single most collected item in beach clean-ups and litter surveys.
\end{abstract}

Methods We searched the Legacy Tobacco Documents Library (http://legacy.library.ucsf.edu) and http:// tobaccodocuments.org using a snowball strategy beginning with keywords (eg, 'filter', 'biodegradable', 'butts'). Data from approximately 680 documents, dated 1959-2006, were analysed using an interpretive approach.

Results The tobacco industry has feared being held responsible for cigarette litter for more than 20 years. Their efforts to avoid this responsibility included developing biodegradable filters, creating anti-litter campaigns, and distributing portable and permanent ashtrays. They concluded that biodegradable filters would probably encourage littering and would not be marketable, and that smokers were defensive about discarding their tobacco butts and not amenable to antilitter efforts.

Conclusions Tobacco control and environmental advocates should develop partnerships to compel the industry to take financial and practical responsibility for cigarette butt waste.

\section{INTRODUCTION}

The health consequences of tobacco use are well known: tobacco use causes many cancers, as well as heart disease, emphysema and many other illnesss. ${ }^{1}$ If current trends continue, tobacco use will kill 1 billion people worldwide in the 21 st century. ${ }^{1}$ In addition to direct health effects, tobacco growing and curing has environmental impacts resulting from deforestation ${ }^{2}{ }^{3}$ and water contamination due to pesticide use. ${ }^{4}$ Other such harms are just beginning to be understood, ${ }^{5}$ and among these is the environmental damage that littered cigarette butt waste may cause.

\section{The cigarette butt problem}

Cigarette filters are a marketing tool, ${ }^{6}$ originally intended to keep loose tobacco out of the smoker's mouth, ${ }^{7}$ not to protect the health of smokers. Indeed, filters have been implicated in increased rates of adenocarcinoma. ${ }^{8}$ Filters are made of cellulose acetate, which is photodegradable, ${ }^{9}$ but not biodegradable; they trap residues from smoking including arsenic, cadmium and toluene. ${ }^{1}$ In beach clean-up campaigns cigarette butts are consistently found to be the single most collected item. ${ }^{10}$ As many as 5.6 trillion cigarettes or 766571 metric tons of butts are deposited into the environment worldwide every year. ${ }^{11}$ Whether they cause significant environmental damage is unknown, but municipalities and other entities incur substantial costs to clean them up. The city of San Francisco, California, USA, estimates this cost at $\$ 7.4$ million annually. $^{12}$

Numerous proposals have been made to prevent or mitigate cigarette butt pollution, including labelling filters as non-biodegradable, deposit/ return programmes, waste fees, litigation against the tobacco industry to recover clean-up costs, fines levied against consumers or tobacco companies, mandated filter biodegradability, a ban on filters and consumer education. ${ }^{5}$ To date, only consumer education has been used with any consistency, although San Francisco recently imposed a waste fee of $\$ 0.20$ per pack to cigarettes sold within the city. $^{13}$

\section{Littering behaviour}

Why some individuals litter and others do not is not well understood, although it is thought that young adults litter more than other age groups. ${ }^{14-16}$ Littering behaviour can be affected by item type (eg, cigarette butt vs beverage container) and by location (eg, street vs park). ${ }^{15}$ Litterers may not recognise their own behaviour as littering, ${ }^{14}$ making it difficult to target. Most of the literature on littering dates from the 1970s and 1980s, and none deals specifically with cigarette butt waste. It is possible that changing smoking prevalence rates and social attitudes towards smoking have affected cigarette butt littering. The passage of clean indoor air laws may exacerbate the butt waste problem as more cigarettes are smoked outdoors ${ }^{17}$; this hypothesis remains untested.

Nearly every aspect of smoking has been the subject of extensive research by the tobacco industry, frequently years or decades in advance of the published scientific literature. ${ }^{18-20}$ Industry research can help advocates design and implement effective tobacco control policy. ${ }^{21-23}$ Previous studies have shown that the industry has been concerned for decades that cigarette litter might increase the social unacceptability of smoking, inspire support for tobacco control, or result in legislation requiring them to take fiscal or practical responsibility for cigarette waste disposal. As a policy response, the industry has sponsored anti-littering groups, distributed portable ashtrays (frequently branded) and unlocked scheme, see http:// tobaccocontrol.bmj.com/site/ about/unlocked.xhtml 
installed permanent ashtrays in downtown areas of numerous cities. $^{24}$ None of these has solved the problem. This study seeks to illuminate some reasons for this failure by examining tobacco industry research relating to smokers' littering beliefs and behaviours.

\section{METHODS}

Over 10 million tobacco industry internal documents have been released through litigation. ${ }^{25}$ We searched the Legacy Tobacco Documents Library (http://legacy.library.ucsf.edu) using a snowball strategy ${ }^{26}$ beginning with keywords (eg, 'filter', 'biodegradable', 'butts'). Data from approximately 680 documents, dated 1959-2006, were analysed using an interpretive approach $^{27-30}$ in which, 'Each document (is) reviewed carefully and the 'taken for granted' assumptions and viewpoints of the author(s) drawn out'. 31

Many of the documents referenced are focus groups or interviews the tobacco industry commissioned to better inform themselves of smokers' feelings and opinions about cigarette butts and littering (details about focus groups are given in table 1). Focus groups are not intended to be representative and statistically generalisable; rather, they are used to gather impressions about the range of opinions on a given subject ${ }^{49}$; however, the fact that multiple focus groups reported similar ideas suggests that the focus group findings are not entirely anomalous. Most of these focus groups were performed in the late 1990 s or early 21 st century. Some were specifically designed to give the industry guidance about how to address the cigarette litter problem; in others, the issue was raised by smokers as one of the problems of smoking.

\section{RESULTS}

The industry's consistent position has been that 'the responsibility for proper disposal' of cigarette waste belongs to the smoker. $^{24} 50-53$ In hope of persuading them to take that responsibility, the tobacco companies studied smokers' attitudes, beliefs and desires about cigarette butts in inquiries about smokers' ideas for new products, specific studies about litter and tests of marketing material. Common themes emerging from these materials reveal the human element of the butt waste problem.

\section{Smoker beliefs and behaviours \\ Beliefs about filters}

Most smokers realised that filters were not biodegradable ${ }^{32}$; however, there were some smokers who did not. ${ }^{32}$ Some 'rejected, or were unaware, of any environmental impact of butts'. ${ }^{4}$ (Some also believed that Camels in particular had 'cotton, biodegradable' filters $^{33}$-a perception that continues today. ${ }^{55}$ )

The potential toxicity of cigarette filters was noticeably absent from industry discussions of the problem, and smokers appeared oblivious to it. RJ Reynolds (RJR) held a number of 'product ideation' sessions with smokers, ${ }^{33}$ in which smokers suggested solutions to the butt litter problem, including creating edible filters, made of 'mint candy' or 'crackers'. 33 Other suggestions included using the filters as compost or mulch: 'make it work with nature instead of against it'. ${ }^{33}$ One group discussed the idea of dissolving filters, but was concerned about possible harm to the water system. ${ }^{34}$ These focus groups were not designed to constrain ideas to the realistic or feasible; however, even the industry report noted that although smokers said they disliked 'seeing butts in their own yards and in their own ashtrays', they were not 'worried about what butts do to the soil, landfills or rivers'. ${ }^{34}$

\section{Smokers' behaviour and attitudes about butts}

RJR research found that 'Most smokers say they hate to see cigarette litter'. 34 They disliked seeing others empty ashtrays in parking lots or on the street. ${ }^{34}$ They also found butts repugnant when disposed of appropriately, commenting that an ashtray full of butts was 'disgusting', 35 that they didn't want to 'clutter up' ashtrays by using them for cigarettes, ${ }^{35}$ and preferred not to dispose of butts in their cars. ${ }^{56}$

Although a Philip Morris (PM) study found that 'virtually all respondents' felt that litter was a consequence of 'apathy, laziness, and insensitivity', they nonetheless 'admitted that they do litter with cigarette butts'. ${ }^{32}$ Some studies quantified the number of smokers that littered: estimates ranged from $45 \%{ }^{36}$ to $75 \%{ }^{37}$ to $92 \%$ of smokers aged $21-25 .{ }^{37}$ Only slightly more than half of smokers surveyed in the UK had ever used a waste bin for their cigarette butts. ${ }^{37}$

Smokers gave various reasons for littering. Tossing a butt to the ground and stepping on it was felt by some to be a 'natural extension of the defiant/rebellious smoking ritual'. ${ }^{32}$ By contrast, other smokers believed that it was 'a conscientious thing to do', 32 since it eliminated the risk of fire. This logic was particularly prevalent in British studies; over half the respondents in one study, ${ }^{37}$ and over a quarter in another, ${ }^{54}$ mentioned fire risk as a reason for not putting butts in waste bins. $^{56}$

Many smokers suggested that they were compelled to litter, asking, "What else am I going to do with them?"34 Smokers said that they wished they didn't 'have to bury the butt in the bushes', ${ }^{57}$ or 'have to throw them on the ground" ${ }^{35}$ when no ashtray was available. Others similarly wished they 'didn't have to throw the cigarette butt out the window' when driving (emphases added). ${ }^{33}$

Some who 'felt guilty' about smoking 'were interested in unloading their cigarettes as quickly as possible', ${ }^{32}$ and thus disinclined to seek out an ashtray. Similarly, some smokers did not like using ashtrays 'because they can see how many cigarettes they have smoked' ${ }^{58}$ But litter also contributed to guilt. One respondent commented, 'an ash tray emptied in a parking lot... makes us all look like pigs'. ${ }^{34}$

Many smokers made a distinction between cigarette butts and other litter. Focus groups said that 'flicking' a cigarette was 'so widespread' it was 'almost acceptable', and smokers and nonsmokers agreed that this 'was a less flagrant litter violation than tossing a bottle/can'. ${ }^{32} 56$ Some smokers felt they had permission to litter, because cigarette butts were not 'viewed as causing significant harm to the environment'. ${ }^{57}$

Butts and littering annoyed non-smokers. ${ }^{38} 39$ People associated 'heaps of cigarette butts [eg, from dumping auto ashtrays] with a lack of concern for other people, selfishness and an almost personal assault'. ${ }^{4} 59$ Some believed that smokers frustrated by clean indoor air laws were deliberately littering in front of public buildings, to 'send the establishment a message', ${ }^{41}$ or that they littered out of spite. ${ }^{42}$ A PM executive acknowledged that, 'Anecdotally, many non-smokers, and smokers, find [litter] the most offensive element of smoking' 60

\section{Changing the product}

The simplest way to solve the problem, some tobacco company employees suggested, would be to return to unfiltered 


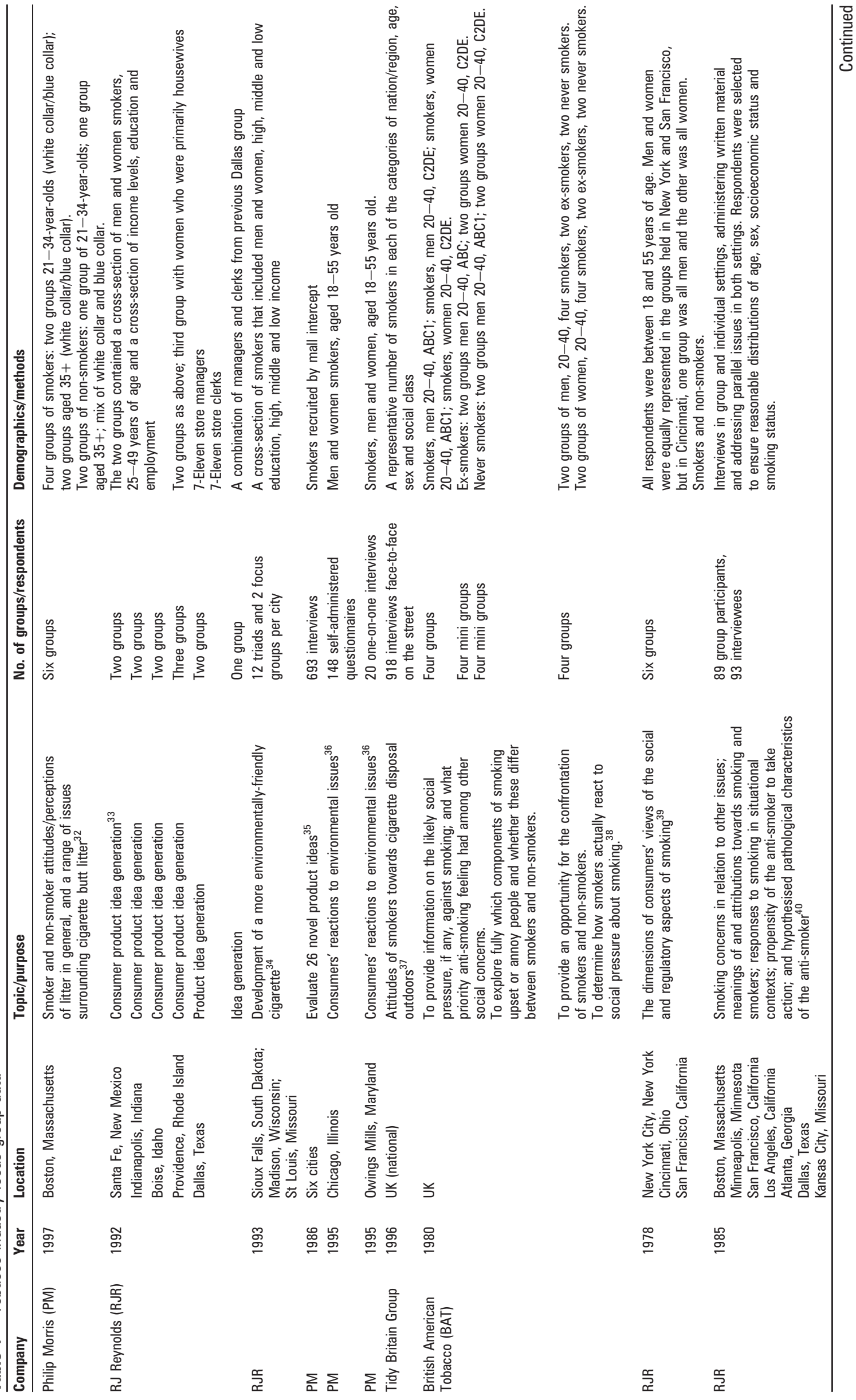




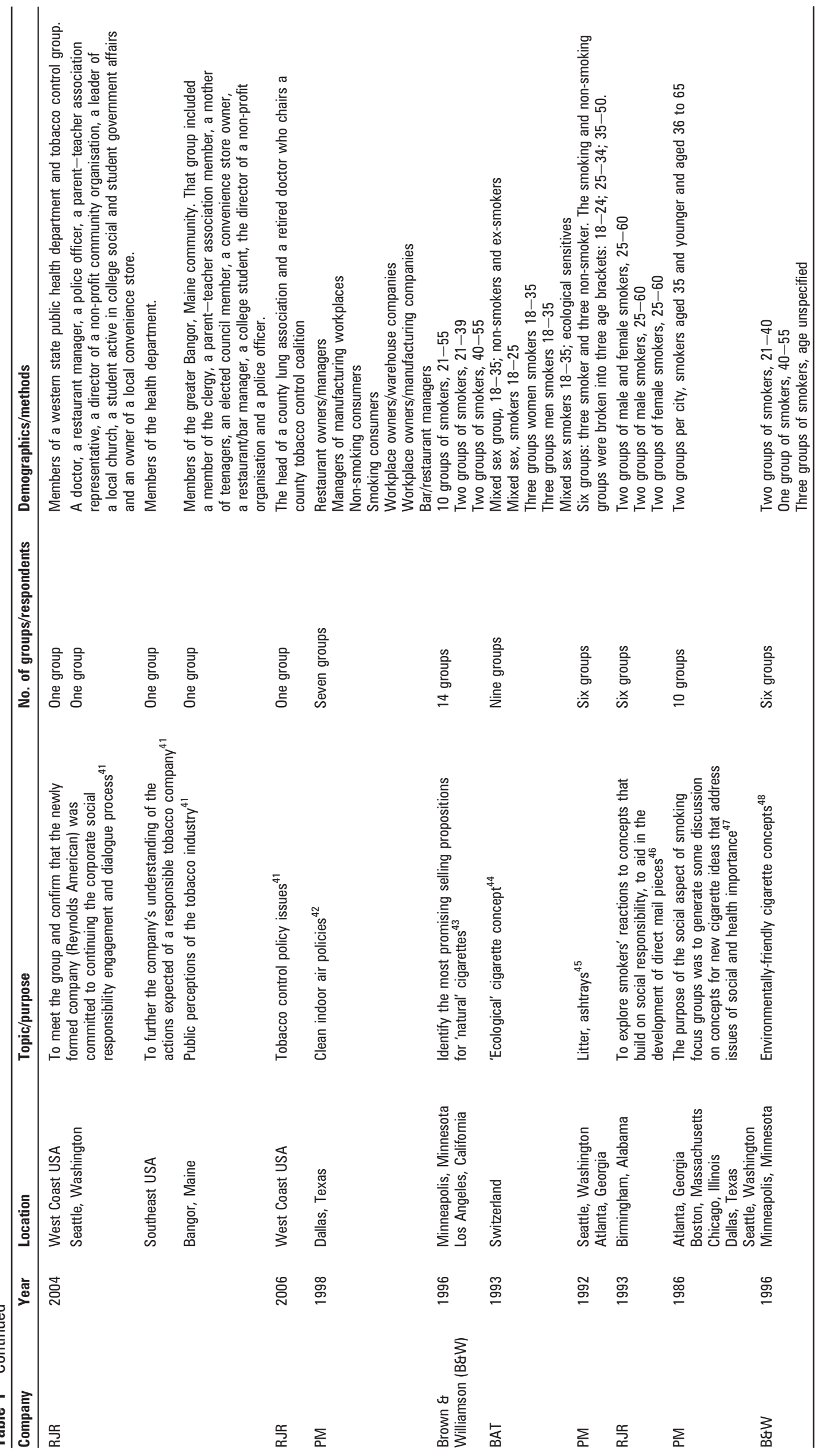


cigarettes. $^{61} 62$ The suggestion was not acted upon; it was believed that it was 'an easier sell to make [filters] biodegradable' than to 'convince people that "unfiltered" cigarettes will still be mild and smooth'. 34 The industry saw several advantages to a biodegradable filter. It might stem the growing disapproval of smokers and of smoking, ${ }^{63}$ prepare the industry for future regulation requiring biodegradability, ${ }^{64} 65$ or even 'pre-empt environmental legislation' ${ }^{\prime 66} 67$ - that is, make regulation appear unnecessary. A biodegradable filter might also improve a company's image, countering 'the negative publicity that the industry receives when litter surveys are published' 68

By contrast, promoting an 'ecofriendly' brand by implication raised questions about the degradability of other cigarettes. ${ }^{66}$ Tobacco companies were reluctant to disclose how poorly filters degraded. RJR frequently claimed that filters were degradable $e^{69-72}$ in 6 months $^{70}$ or 'less than a year'. 72 The company disingenuously claimed that butts were not a litter problem because "practically all the materials we use have a degree of biodegradability'. ${ }^{71}$

The companies knew that biodegradable filters might actually encourage littering. British American Tobacco (BAT) suggested that such filters would offer 'outdoor convenience' by 'eliminating' litter. ${ }^{73}$ A focus group participant wanted biodegradable filters because 'I want to just throw them down, but I don't want to feel bad about it'. ${ }^{44}$ Brown \& Williamson concluded that the 'perceived benefit' of a biodegradable filter was 'the ability to litter without guilt'. 4348

A related problem was that biodegradation was not instantaneous. A focus group report acknowledged that biodegradable filters 'have all of the right buzz-words', but 'they may not degrade as quickly as smokers really want'. ${ }^{34}$ Smokers wanted a butt that disappeared. ${ }^{33}$ A BAT report concluded that 'it is clear that a cigarette butt that miraculously vanishes, leaving behind it no distasteful sight or smell would represent a huge step forward for both smoker and non-smoker'.38 The question for the industry was whether anything less would satisfy the claim of biodegradability.

Finally, there was a tension between using biodegradable filter technology to benefit a particular company, and using it to improve the image ${ }^{33} 74$ (and self-image) ${ }^{44}$ of smokers. BAT was 'looking for a market lead and therefore commercial secrecy' ${ }^{, 64}$ about such technology, but the company also recognised that, 'When all discarded filter tips look alike to the public the fact that some degrade more quickly than others may be of academic interest only, if the majority do not. For certain it is fanciful to expect gratuitous attribution of success from the public through elimination of only a small part of the problem, 75

\section{Changing smoker behaviour \\ Anti-litter campaigns}

Several tobacco companies developed anti-litter campaigns, ${ }^{76} 77$ deciding that the solution was 'education(,) not materials science'. ${ }^{78}$ However, industry research suggested that such a campaign had to be formulated carefully. Smokers feared that an anti-litter campaign could become 'another thing nonsmokers can attack us for'. ${ }^{32}$ Thus, although most smokers admitted to littering, they felt defensive since butts were 'just a small part of a big problem'. ${ }^{79}$ Even though the campaigns were supposed to make smokers aware that butts were litter, ${ }^{80}$ they could not single out smokers as litterers or equate smoking with littering. ${ }^{32}$ Smokers preferred slogans defining the problem 'as a litter issue rather than a smoking issue'. 54

Smokers were sensitive to anything that could be interpreted as accusatory or critical, ${ }^{32} 54$ preferring a 'gentle nudge' to modify their behaviour. ${ }^{58}$ In Australia, smokers accepted a 'Please bin your butts' campaign, feeling that it was non-confrontational and acknowledged the right to smoke. ${ }^{54}$ However, in the US, although focus group members appreciated being reminded of their 'rights', they 'did not want to be part of 'another cigarette controversy". 57

In the US, smokers liked the slogan, 'a little thought, a lot less litter'. ${ }^{32}$ (A version of this slogan, 'A Little More Thought-Less Littered Butts!' can be found on the Keep America Beautiful website. ${ }^{81}$ ) The request for 'more thought' was 'comfortable and acceptable'. ${ }^{32}$ In contrast, slogans suggesting that smokers 'pick up' their litter were rejected: although they might be persuaded to dispose appropriately of a butt they were holding, they were unlikely to pick one up once they dropped it. $^{45} 57798082$

The imagery accompanying such campaigns was also a matter of concern. Most significantly, images of cigarette butts-the focus of the effort-were 'extremely uncomfortable for some smokers' and thus to be avoided. ${ }^{32} 82$ Even the favoured slogan, 'a little thought, a lot less litter' was rejected when depicted with cigarette butts. ${ }^{32}$

\section{Portable ashtrays}

Smokers were ambivalent about portable ashtrays. Some, ranging from $15 \%{ }^{83}$ to $53 \%$, and up to $61 \%$ of women, said they would find such an item useful. ${ }^{84}$ In one test, nearly $60 \%$ of those receiving sample ashtrays claimed they used them 'at least 1-2 times a week' and some said the ashtrays had 'made them pay closer attention to cigarette disposal'. 85 Smokers thought the ashtrays would be useful in places such as public parks, golf courses, ${ }^{57}$ 'outside at work, outside the respondent's home, outside others' homes, and in the car'. ${ }^{57}$ They also said they would use the ashtrays to 'convey a positive personal image around non-smokers'. 57

However, some smokers were 'less enthusiastic' because they didn't 'feel a need to use an ashtray to dispose of cigarettes outdoors'. ${ }^{46}$ Some claimed they smoked 'only in places where there are ashtrays', or disposed of butts in other ways. ${ }^{84}$ Other smokers felt they would 'forget to use or carry' it, ${ }^{84}$ especially because 'the process of flicking a cigarette butt on the ground is a well-ingrained, reflexive habit' ${ }^{32}$ Smokers also worried that the ashtrays would be smelly, ${ }^{32} 3584$ messy, $^{32} 47$ or dirty ${ }^{84}$ and called carrying butts around in them 'revolting'. ${ }^{35}$ These smokers felt that 'It would be easier to throw the cigarette on the ground'. 35 In response to these concerns, RJR stressed that the ashtrays were a temporary means of disposal, to be emptied as soon as practicable. $^{69}$

\section{Permanent ashtrays}

Tobacco companies and smokers frequently suggested that the cigarette litter problem was the result of clean indoor air laws causing more smoking outdoors, ${ }^{34} 515386-89$ where there were insufficient ashtrays. ${ }^{32} 51 \quad 538990$ However, the impact of permanent ashtrays was questionable. Employers who placed them in outdoor smoking areas commented, for example, that 'There are 30 butts in the ashtray and 100s around it'. ${ }^{91}$ Studies noted that cigarette butt litter was often found "within $5 \mathrm{~m}$ of a bin', ${ }^{92}$ and about half of smokers said they would not bother to use an ashtray if it were 'more than 10 paces' away ${ }^{37}$; only 
a third said they would walk further. ${ }^{93}$ Half of Australian smokers said that if they 'knew it was a littering problem' they would 'make an effort' to use an ashtray, and 20\% said they would use a convenient ashtray, but wouldn't go out of their way to use one. ${ }^{54} \mathrm{PM}$ found that although $72 \%$ of smokers who noticed the ashtrays they had installed said they used them, only $20 \%$ noticed them. ${ }^{94}$

\section{DISCUSSION}

This study has limitations. The document set is not comprehensive, but a selection of litigation-related material. There has been no tobacco litigation to date concerning tobacco litter/waste issues, and there may be documents that contain additional information that could be revealed in the discovery process. We also may not have identified all relevant available documents due to the volume of the tobacco documents library.

The tobacco industry's research shows how much smokers disliked cigarette butts, littered or in ashtrays. Smokers found them smelly and dirty; they were unwilling to put them in their car ashtrays, carry them around in portable ashtrays, or hold them for more than a few steps to discard them appropriately. Creating butt litter made smokers uncomfortable even as they did it. Furthermore, smokers had multiple, sometimes conflicting, reasons for littering their butts: it was conscientious and rebellious, and it minimised their contact with an unpleasant reminder of their addiction. As the industry found, the complex psychology of butt littering made difficult identifying any message that might change the behaviour.

The tobacco companies perceived cigarette butt waste as a vulnerability that tobacco control advocates might exploit. Thus, they were motivated to solve the problem. However, the industry would not promote any messages that criticised smokers or called into question smoking itself. Their efforts-anti-litter campaigns and handheld and permanent ashtrays-did not substantially affect smokers' entrenched 'butt flicking' behaviours. These findings suggest that tobacco control programmes should not attempt to solve the problem by providing ashtrays or enhancing antilittering laws. Attempts to change the behaviour of smokers should focus on cessation.

More to the point, tobacco control should place the burden of cigarette waste on the industry. For more than 30 years the tobacco companies have feared the establishment of legislation or regulation compelling them to take responsibility for cigarette butt waste. Only recently has butt waste been framed as an economic and quality of life issue, ${ }^{5}$ as opposed to an aesthetic problem. Such redefinition may encourage efforts to make the industry responsible for the toxic waste produced by smoking cigarettes. In other environmental waste areas, attention is focused on the waste producer. For example, the European Union Waste Electrical and Electronic Equipment directive makes producers and retailers responsible for recycling their products. ${ }^{95}$

Policy makers should be made aware that the presence of filters implies a degree of safety to smokers, but does not reduce smoking-caused disease, and that cigarette butt waste incurs a cost to communities and to the environment. Reconceptualising butt waste as an 'upstream' problem created by the tobacco industry may facilitate partnerships between environmental and tobacco control groups, leading to more innovative policy solutions that discourage smoking and place the cost and consequences of filter waste on the tobacco industry.

Funding This research was funded by the California Tobacco-Related Diseases Research Program Grant \#17IT-0014 and National Cancer Institute Grant \#CA120138.

Competing interests ES was a consultant for the US Justice Department it its case against the tobacco industry.

Contributors ES performed the research and initial draft of the paper; TN conceptualised the project and participated in the writing of the paper

Provenance and peer review Not commissioned; externally peer reviewed.

\section{REFERENCES}

1. Shafey 0, Eriksen M, Ross H, et al. The Tobacco Atlas. 3rd edn. Atlanta, GA: American Cancer Society, 2009

2. Loker WM. The rise and fall of flue-cured tobacco in the Copán Valley and its environmental and social consequences. Human Ecology 2005;33:299-327.

3. Mwita MM. Ecological impact of tobacco farming in miombo woodlands of Urambo District, Tanzania. Afr J Ecol 2005;43:385-91.

4. Novotny TE, Zhao F. Consumption and production waste: another externality of tobacco use. Tob Control 1999:8:75-80.

5. Novotny TE, Lum K, Smith EA, et al. Cigarette butts and the case for an environmental policy on hazardous cigarette waste. Int J Environ Res Public Health 2009;6:1691-705

6. Brandt AM. The Cigarette Century: The Rise, Fall, and Deadly Persistence of the Product that Defined America. New York, NY: Basic Books, 2007.

7. Pauly JL, Mepani AB, Lesses JD, et al. Cigarettes with defective filters marketed for 40 years: what Philip Morris never told smokers. Tob Control 2002;11 (Suppl 1): |51-61.

8. Gray N. The consequences of the unregulated cigarette. Tob Control 2006;15:405-8.

9. Hon N-S. Photodegradation of cellulose acetate fibers. J Polymer Sci Polymer Chem Ed 1977:15:725-44.

10. International Coastal Cleanup: a rising tide of ocean debris. 2009 http://www.oceanconservancy.org/pdf/A_Rising_Tide_full_lowres.pdf (accessed 23 Nov 2010).

11. Carlozo LR. Cigarettes: 1.7 billion pounds of trash. 2008. http://articles. chicagotribune.com/2008-06-18/features/0806170174_1_cigarette-buttssecondhand-beach-house (accessed 22 Nov 2010).

12. Schneider JE, Decker CS, Doyle A, et al. Estimates of the Costs of Tobacco Litter in San Francisco and Calculations of Maximum Permissible Per-Pack Fees. Morristown, $\mathrm{NJ}$ : Health Economics Consulting Group, 2009.

13. City and County of San Francisco. Ordinance 173-09. Cigarette Litter Abatement Fee Ordinance. City and County of San Francisco, 2009

14. Robinson SN. Littering behavior in public places. Environ Behav 1976:8:363-84.

15. Spehr K, Curnow R. Improving disposal behavior in the city of Melbourne. 2003 http://www.ecorecycle.sustainability.vic.gov.au/resources/documents/JRG MelbDisposal_Aug03.pdf (accessed 23 Nov 2010)

16. Wells DL. Factors influencing owners' reactions to their dogs' fouling. Environ Behav 2006:38:707-14.

17. Clean Virginia Waterways. Cigarette butt litter. 2006. http://www.longwood.edu/ CLEANVA/cigbuttsmokingbans.htm (accessed 29 Sep 2009)

18. Stevenson T, Proctor RN. The secret and soul of Marlboro: Philip Morris and the origins, spread, and denial of nicotine freebasing. Am J Public Health 2008:98:1184-94.

19. Ling PM, Glantz SA. Using tobacco-industry marketing research to design more effective tobacco-control campaigns. JAMA 2002;287:2983-9.

20. Ling PM, Glantz SA. Tobacco industry consumer research on socially acceptable cigarettes. Tob Control 2005;14:e3.

21. McDaniel PA, Smith EA, Malone RE. Philip Morris's Project Sunrise: weakening tobacco control by working with it. Tob Control 2006;15:215-23.

22. McDaniel PA, Malone RE. Understanding Philip Morris's pursuit of US government regulation of tobacco. Tob Control 2005;14:193-200.

23. Bero LA. Implications of the tobacco industry documents for public health and policy. Annu Rev Public Health 2003;24:267-88.

24. Smith EA, McDaniel PA. Covering their butts: responses to the cigarette butt litter problem. Tob Control Published Online First: 21 Oct 2010. doi:10.1136/ tc. 2010.036491

25. National Association of Attorneys General. Master settlement agreement. 1998. http://www.naag.org/backpages/naag/tobacco/msa/msa-pdf (accessed 3 Mar 2009).

26. Malone RE, Balbach ED. Tobacco industry documents: treasure trove or quagmire? Tob Control 2000;9:334-8.

27. Taylor C. Theories of meaning. In: Taylor C, ed. Human Agency and Language: Philosophical Papers 1. Cambridge [Cambridgeshire]. New York, NY: Cambridge University Press, 1985:248-92. 
28. Taylor C. Interpretation and the sciences of man. In: Taylor C, ed. Human Agency and Language: Philosophical Papers 2. Cambridge [Cambridgeshire]. New York, NY: Cambridge University Press, 1985:33-81.

29. Van Manen M. Researching Lived Experience: Human Science for an Action Sensitive Pedagogy. Albany, NY: State University of New York Press, 1990.

30. Hill MR. Archival Strategies and Techniques. Newbury Park, CA: Sage Publications, 1993.

31. Forster N. The analysis of company documentation. In: Cassell C, Symon G, eds. Qualitative methods in organizational research: a practical guide. London: Sage Publications, 1995:147-66.

32. The Cigarette Butt Litter Issue - Exploratory Research: Philip Morris, 1997. http://legacy.library.ucsf.edu/tid/mbj05c00 (accessed 14 Nov 2008).

33. Fay JE, Dube M. R. J. Reynolds Tobacco Co. Research \& Development Creativity Workshop: RJ Reynolds, 1992. http://legacy.library.ucsf.edu/tid/lof43d00 (accessed 22 May 2009).

34. Fay JE. Environmentally-Friendly Cigarette Focus Groups in Sioux Falls, SD; Madison, Wl: and St. Louis, MO - April 13-15, 1993: RJ Reynolds, 1993. http://legacy. library.ucsf.edu/tid/myl38c00 (accessed 14 Nov 2008).

35. Jones JA, Martin P. New Product Concept Evaluation - Qualitative Results: Philip Morris, 1986. http://legacy.library.ucsf.edu/tid/fxx88e00 (accessed 21 May 2009)

36. Callaham P. Summary of Environmental Qualitative Research: Philip Morris, 1995 http://legacy.library.ucsf.edu/tid/aur06c00 (accessed 18 Jun 2009).

37. Tidy Britain Group. [Attitudes Towards Cigarette Disposal Outdoors]. Philip Morris, 1996. http://legacy.library.ucsf.edu/tid/gkq47d00 (accessed 05 Dec 2008).

38. Project Aries: Qualitative Findings. British American Tobacco, 1980. http://legacy library.ucsf.edu/tid/vva64a99 (accessed 14 Apr 2009).

39. AHF Marketing Research. SOSAS Developmental Stage Summary: RJ Reynolds 1978. http://legacy.library.ucsf.edu/tid/txc69d00 (accessed 28 Apr 2009).

40. Anti-Smoking: the Organized Movement and Individual Orientations: RJ Reynolds, 1985. http://legacy.library.ucsf.edu/tid/atm97c00 (accessed 28 Apr 2009).

41. Section 5 Intro \& Stakeholder Engagement \& Dialogue Sections: RJ Reynolds, 2006. http://legacy.library.ucsf.edu/tid/yxu27a00 (accessed 18 May 2009).

42. Grubbs J, Williams BM. Focus Group Re-Cap: Philip Morris, 1998. http://legacy. library.ucsf.edu/tid/ndr20b00 (accessed 29 Apr 2009).

43. Gelson E. Project Nadir Report: Brown \& Williamson, 1996. http://legacy.library.ucsf. edu/tid/nmu91d00 (accessed 27 Jul 2009).

44. Alexander Concept-Test Qualitative Research: Final Report: British American Tobacco, 1993. http://legacy.library.ucsf.edu/tid/wqu70a99 (accessed 19 Jun 2009).

45. Slavitt J. Results of Ashtray Survey: Philip Morris, 1992. http://legacy.library.ucsf edu/tid/isl24e00 (accessed 5 Dec 2009).

46. Gene Shore Associates. R.J. Reynolds Vantage Positioning Communication Exploratory Focus Groups II: RJ Reynolds, 1993. http://legacy.library.ucsf.edu/tid/ dqw13d00 (accessed 1 Dec 2008)

47. Wu L. Results of the Social Aspects of Smoking Focus Groups 860707-860710: Philip Morris, 1986. http://legacy.library.ucsf.edu/tid/jng07e00 (accessed 21 May 2009)

48. Heironimus J. Nadir Research: Brown \& Williamson, 1996. http://legacy.library.ucsf. edu/tid/dty03f00 (accessed 5 Dec 2008).

49. Morgan DL. The Focus Group Guidebook. Thousand Oaks, CA: Sage, 1998

50. Johnston JW. Thank you for your Recent Inquiry to Louis Gerstner of RJR Nabisco and me About Environmental Practices by the Tobacco Industry: RJ Reynolds, 1992. http://legacy.library.ucsf.edu/tid/rod11d00 (accessed 18 May 2009).

51. British American Tobacco. TAC contingency media response to enquiries about the Tidy Britain Group's 1993 UK litter survey. 1993. http://legacy.library.ucsf.edu/tid/ xhk30a99 (accessed 19 Jun 2009).

52. Culley L, Eiger R, Folie M. Re: Chairman's BB/TAP, Smoking Restrictions. Philip Morris, 1998. http://legacy.library.ucsf.edu/tid/bct94c00 (accessed 14 Nov 2008).

53. PM USA Chairman's Briefing Book: Philip Morris, 1999. http://legacy.library.ucsf.edu/ tid/xfz56c00 (accessed 28 Apr 2009)

54. N403 [Please Bin Your Butts: Research on Cigarette Littering, Stage 3-Smoker Survey]. Philip Morris, 1998. http://legacy.library.ucsf.edu/tid/hkq47d00 (accessed 14 Nov 2008)

55. Camel cigarette butts biodegradable? 2008. http://answers.yahoo.com/question/ index?qid=20080722123930AAsy1WZ (accessed 14 Aug 2009)

56. Campbell F. No butts: smoking-related litter. 2008. http://www.keepbritaintidy.org/ ImgLibrary/smoking 652.pdf (accessed 23 Nov 2010).

57. Philip Morris Litter Communication Program: Philip Morris, 1998. http://legacy.library. ucsf.edu/tid/fyr14a00 (accessed 1 Dec 2008)

58. Ural E. Summary of Litter Research Findings: Philip Morris, 1998 http//legacy. library.ucsf.edu/tid/cag37c00 (accessed 14 Nov 2008).

59. Worsham JR. Smokers Do It and Then They Toss Their Butts: Tobacco Institute, 1992. http://legacy.library.ucsf.edu/tid/zkk12f00 (accessed 14 Nov 2008).
60. Lund N. Revised Strategy and Actions Presentation: Philip Morris, 1999 http://legacy.library.ucsf.edu/tid/yex75c00 (accessed 27 Apr 2005)

61. Delta Research, Fay JE. R.J. Reynolds Tobacco Co. Ideation for Product Development Meeting on Hilton Head Island: RJ Reynolds, 1992. http://legacy.library. ucsf.edu/tid/swb33d00 (accessed 14 Nov 2008).

62. Kern CC. [Memo on Pall Mall Product Concepts]. American Tobacco, 1985. http:// legacy.library.ucsf.edu/tid/scx25f00 (accessed 2 Dec 2008).

63. A Second Proposal for Industry Litter Policy: Tobacco Institute, 1979 (est). http:// legacy.library.ucsf.edu/tid/nuz30c00 (accessed 4 Dec 2008).

64. Luke JA. Degradability of Filter Materials and Plastics Packaging: British American Tobacco, 1991. http://legacy.library.ucsf.edu/tid/rvj95a99 (accessed 19 Jun 2009).

65. Carson JW, McCarthy BW. Report of the Final Days of the Scimitar Campaign for BAT (UK \& Export) Limited held on 18th \& 19th July, 1990: British American Tobacco, 1990. http://legacy.library.ucsf.edu/tid/cgz82a99 (accessed 24 Jun 2009)

66. [Problem Statement on Filter Litter]. Philip Morris, 1994. http://legacy.library.ucsf.edu/ tid/hvx21b00 (accessed 18 Jun 2009).

67. Cato Gobe. Project Ecco-Smoke: A Strategic Opportunity for the Philip Morris Tobacco Company: Philip Morris, 1991. http://legacy.library.ucsf.edu/tid/kse11b00 (accessed 28 Apr 2009)

68. CORESTA Cigarette Butt Degradability Task Force (CBDTF): Third Meeting 10th March 1994 London: British American Tobacco, 1994. http://legacy.library.ucsf.edu/tid/ ouu74a99 (accessed 25 Jun 2009)

69. Whitt DD. Portable Ashtray Q\&A: RJ Reynolds, 1991. http://legacy.library.ucsf.edu/ tid/eij43d00 (accessed 14 Nov 2008)

70. Daytona Beach Program Clean-up Program: RJ Reynolds, 1991. http://legacy.library ucsf.edu/tid/wtw14d00 (accessed 1 Dec 2008).

71. Usrey MA. Thank You for Your Letter of January 3: RJ Reynolds, 1992. http://legacy. library.ucsf.edu/tid/wcb38c00 (accessed 2 Dec 2008)

72. Environmental Issues: RJ Reynolds, 1998. http://legacy.library.ucsf.edu/tid/nnb46a00 (accessed 18 May 2009).

73. McCarthy B. Letter from Brian McCarthy to RP Ferris enclosing report from the BAT Scimitar programme: British American Tobacco, 1990. http://legacy.library.ucsf.edu/ tid/ocp42a99 (accessed 19 Jun 2009)

74. PDT Meeting 3 94. British American Tobacco, 1994. http://legacy.library.ucsf.edu/tid/ xbs64a99 (accessed 27 Jul 2009).

75. Degradability of Cigarette Filter Tips: British American Tobacco, 1991. http://legacy library.ucsf.edu/tid/tvj95a99 (accessed 19 Jun 2009).

76. PM Corporate Affairs: Robinson \& Maites litter program development scope-of-work: Philip Morris, 1997. http://legacy.library.ucsf.edu/tid/bhm16c00 (accessed 14 Nov 2008).

77. Corporate Affairs Gameplan: Philip Morris, 2002. http://legacy.library.ucsf.edu/tid/ kir02c00 (accessed 2 Jul 2009).

78. Luke J, Wiethaup W. Cigarette Filter Degradability: British American Tobacco, 1991 http://legacy.library.ucsf.edu/tid/esj21a99 (accessed 19 Jun 2009).

79. Gene Shore Associates. R.J. Reynolds Vantage Positioning Communication Exploratory Focus Groups: RJ Reynolds, 1992. http://legacy.library.ucsf.edu/tid/ ssj13d00 (accessed 3 Dec 2008)

80. Robinson \& Maites. [The R\&M Creative Brief]. Philip Morris, 1998. http://legacy. library.ucsf.edu/tid/ovg27d00 (accessed 5 Dec 2008).

81. Keep America Beautiful. Cigarette litter prevention program. 2009. http://www kab.org/site/PageServer?pagename=CLPP landing (accessed 28 Jul 2009)

82. N331 [Litter - Direct to Consumer]. Philip Morris, 1998. http://legacy.library.ucsf. edu/tid/pvg27d00 (accessed 22 May 2009).

83. Adams C, Jeltema M. Analysis of Cost - Benefit Study Data: Philip Morris, 1996. http://legacy.library.ucsf.edu/tid/bdc93c00 (accessed 22 May 2009).

84. English M. Portable Pocket Ashtray Data from CTS: Philip Morris, 1998. http:// legacy.library.ucsf.edu/tid/zlj05c00 (accessed 5 Dec 2008).

85. Portable Ashtray Telephone Research - Final Report: Philip Morris, 1999. http:// legacy.library.ucsf.edu/tid/ncb87a00 (accessed 18 Jun 2009)

86. Cooke H, Mallone M, McDonald S, et al. Ark Research Report Cigarette Butt Litter Philip Morris, 1995. http://legacy.library.ucsf.edu/tid/hcb83c00 (accessed 14 Nov 2008)

87. TMA World Alert: Philip Morris, 2001. http://legacy.library.ucsf.edu/tid/nve17a00 (accessed 26 Jun 2009).

88. Smith MD. CSR Report 2004-2006: RJ Reynolds, 2006. http://legacy.library.ucsf edu/tid/hju27a00 (accessed 5 Dec 2008).

89. Windholz EL. Accommodation/Courtesy of Choice Materials: Philip Morris, 1997 http://legacy.library.ucsf.edu/tid/vte77a00 (accessed 11 Jun 2009)

90. Tomb H. Philip Morris Fights Litter: Philip Morris, 1999. http://legacy.library.ucsf.edu/ tid/gq006c00 (accessed 1 Dec 2008)

91. Holm P. Ventilation Research - Overview by Types of Workplace:

Philip Morris, 1998. http://legacy.library.ucsf.edu/tid/uhv70b00 (accessed 14 Aug 2009) 
92. Environmental Newsletter No. 30 Environmental Issue Tracking - Asia Pacific Region: Philip Morris, 1999. http://legacy.library.ucsf.edu/tid/ilg42c00 (accessed 28 Apr 2009).

93. RJ Reynolds International. RJRI News Report. Wednesday, December 04, 1996: RJ Reynolds, 1996. http://legacy.library.ucsf.edu/tid/dxg65a00 (accessed 22 May 2009).
94. Philip Morris USA Litter Program Executive Summary of Research Findings: Philip Morris, 2000. http://legacy.library.ucsf.edu/tid/vay65c00 (accessed 14 Nov 2008).

95. Schneiderman R. Electronic waste: be part of the solution. 2004. http:// electronicdesign.com/article/components/electronic-waste-be-part-of-thesolution7820.aspx (accessed 22 Jan 2010).

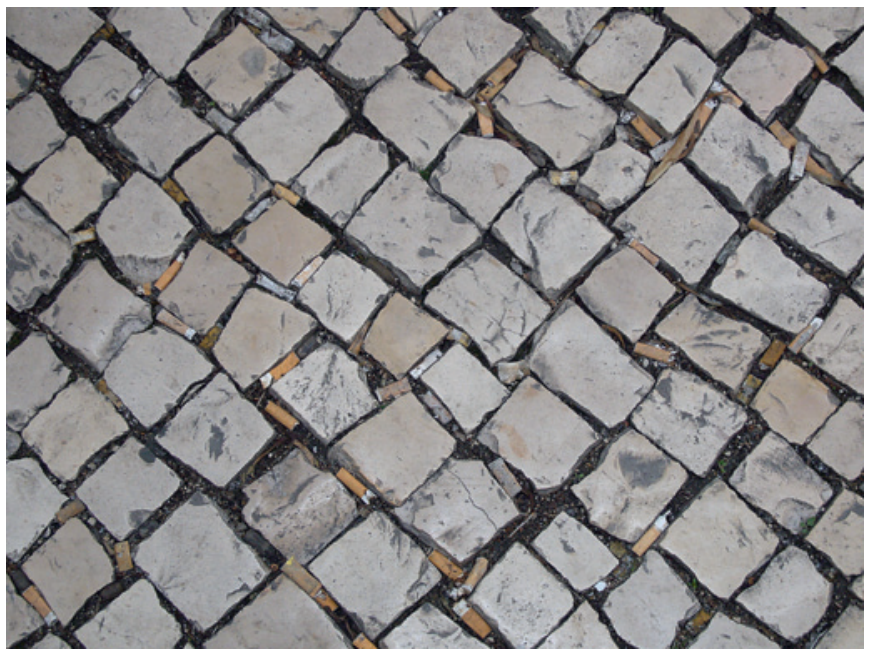

